JURNAL MAKSIPRENEUR, Vol. VI, No. 2, Juni 2017, hal. 27 - 35

\title{
PENGEMBANGAN PRODUK DAN INOVASI PRODUK PADA TEH HIJAU CAP POHON KURMA (STUDI PADA PT PANGUJI LUHUR UTAMA)
}

\author{
Bambang Purnomo \\ Fakultas Keguruan dan Ilmu Pendidikan Universitas Dr Soetomo Surabaya \\ Bambang Raditya Purnomo \\ Fakultas Ekonomi dan Bisnis Universitas Dr Soetomo Surabaya
}

Korespondensi penulis: bambang.purnomo@unitomo.ac.id

\begin{abstract}
This research aims to explain and analyze product development strategy and product innovation of Green Tea Cap Pohon Kurma. The descriptive method with a qualitative approach is a type of research used by researchers. The purpose of this research can be described the actual situation in accordance with reality, digging, and analyzing more deeply related to product development strategy and product innovation by using observation, interview, and documentation in data collection techniques. The results of this study indicate that the process of product development should be done proactively to pay attention to financial performance of company (financial performance) so that what is expected by consumer in market can also fulfill the expectation from shareholders (stockholders).
\end{abstract}

Keywords: product development, product innovation, green tea, descriptive qualitative.

\section{PENDAhULUAN}

Persaingan bisnis consumer goods telah menunjukkan bentuknya yang khas yaitu persaingan untuk memperbesar ekuitas merek (brand equity) dan memperbesar sales volume melalui penguasaan jalur distribusi yang disertai dengan peningkatan kualitas produk. Di samping itu, usaha untuk mengembangkan produk melalui product development dan product innovation menjadi sangat menentukan dan sangat kritikal teruatama pada era perkembangan zaman yang semakin cepat dan selalu berubah-ubah mengikuti perubahan pola gaya hidup para trend setter. Sejak akhir dekade ini banyak produsen consumer goods yang mulai meningkatkan layanannya demi mencapai consumer satisfaction yang selalu menjadi tujuan utama perusahaan. Bahkan, saat ini banyak perusahaan yang menerapkan tujuan perusahaan lebih tinggi yaitu customer delightness, sehingga perusahaan berlomba-lomba menyenangkan konsumennya dengan mengembangkan produk baru dan melakukan inovasi produk.

Hal ini juga terjadi pada komoditi teh hijau. Konsumsi teh, baik teh hijau maupun teh hitam mengalami perjalanan yang menarik untuk disimak dan diikuti, sehingga bila Indonesia hendak memasuki kancah bisnis agroindustri akan perlu mempelajari secara mendalam perkembangan pasar serta perilaku konsumen yang langsung mengkonsumsi teh ini. Masyarakat di Jepang telah lama mengkonsumsi teh karena kultur konsep hidup sehatnya. Dengan demikian, konsep nilai (value concept) terhadap produk teh hijau 
pada masyarakat Jepang sudah sedemikian favourable dan mampu menunjang pertumbuhan industri minuman teh hijau. Apabila teh hijau dianggap sebagai produk yang memiliki keunggulan kompetitif dan merupakan core competence bangsa Indonesia, maka sudah selayaknyalah bila usaha untuk meningkatkan eksistensi produk teh hijau ini digencarkan, sehingga menjadi peluang untuk menguasai segmen pasar tertentuyang secara loyal mengkonsumsi teh hijau produk asli Indonesia.

Situasi pasar industri minuman saat ini diwarnai dengan persaingan yang sangat sengit dan ketat baik dalam pasar domestik maupun pasar internasional. Produk industri minuman yang beredar di pasaran terdiri atas beraneka jenis produk atara lain: (1) industri minuman berkarbonasi misalnya Coca Cola, Pepsi, Soda F\&N dan lainnya, (2) industri minuman non-karbonasi misalnya teh botol Sosro, susu Ultra Jaya, Punch, dan lainnya, (3) industri minuman dengan tambahan alkohol misalnya Greend Sand, Shandy dan lainnya. Ada pun pelaku bisnis dalam pasar produk teh hijau sendiri menurut data dari Kementerian Perdagangan RI terdapat lebih dari lima puluh produsen teh hijau di Indonesia. Hampir keseluruhan proses produksi teh hijau tersebut dikelola secara tradisional dalam artian selalu diproses dengan teknologi yang diwariskan dari generasi ke generasi untuk mengembangkan produk secara lebih canggih.

Produk Teh Hijau Cap Pohon Kurma berasal dari perkebunan teh Jamus di wilayah Ngawi Jawa Timur dan selanjutnya diangkut untuk proses produksi di Pekalongan Jawa Tengah. Proses produksi ini mengakibatkan tambahan biaya yang cukup nyata, sehingga mengakibatkan harga jualnya menjadi lebih tinggi, tetapi tetap diimbangi dengan mutu produk yang tinggi. Dalam praktik bisnisnya, sebagian produknya juga dibeli oleh para produsen teh wangi lainnya, sehingga dalam hal ini PT Panguji Luhur Utama (PLU) berfungsi sebagai pemasok produk setengah jadi yang akan diolah lebih lanjut oleh para produsen lain yang juga merupakan kompetitornya. Dengan bertindak seperti itu, sebenarnya PLU mengalami kerugian karena pendapatannya menjadi lebih rendah serta membesarkan kompetitor yang berfungsi hanya sebagai reseller. Pada awal tahun 1997, manajemen PLU telah mampu mengadakan kontak dagang internasional untuk menjual Teh Hijau Cap Pohon Kurma ke Timur Tengah. Pasar Timur Tengah ini memang tidak seberat pasar Amerika atau pasar Jepang, sehingga kesempatan ini merupakan tahap belajar untuk terus memperhatikan mutu dan selera konsumen dunia yang berbeda satu sama lain.

\section{KAJIAN PUSTAKA}

\section{a. Pengembangan Produk}

Pengembangan produk merupakan aktivitas lintas disiplin yang membutuhkan kontribusi dari hampir semua fungsi yang ada di perusahaan, tetapi tiga fungsi yang selalu paling penting bagi proyek pengembangan produk (Cross, 1994) adalah:

1. Pemasaran. Fungsi pemasaran adalah menjembatani interaksi antara perusahaan dengan pelanggan. Peranan lainnya adalah memfasilitasi proses identifikasi peluang produk, pendefinisian segmen pasar, dan identifikasi kebutuhan pelanggan. Bagian pemasaran juga secara khusus merancang komunikasi antara perusahaan dengan pelanggan, menetapkan target harga dan merancang peluncuran serta promosi produk.

2. Perancangan (disain). Fungsi perancangan memegang peranan penting dalam mendefinisikan bentuk fisik produk agar dapat memenuhi kebutuhan pelanggan. Dalam konteks tersebut tugas bagian perancangan mencakup disain engineering 
(mekanik, elektrik, software, dan lain-lain) dan disain industri (estetika, ergonomi, user interface).

3. Manufaktur. Fungsi manufaktur terutama bertanggung jawab untuk merancang dan mengoperasikan sistem produk pada proses produksi produk. Fungsi ini mencakup pembelian, instalasi, dan distribusi.

Proses pengembangan produk menurut Urich dan Eppinger dalam bukunya yang berjudul Perancangan dan Pengembangan Produk (2001, p14) terdiri atas enam fase yaitu:

1. Fase 0: Perencanaan Produk

Kegiatan perencanaan sering dirujuk sebagai "zero fase" karena kegiatan ini mendahului persetujuan proyek dan proses peluncuran pengembangan produk aktual.

\section{Fase 1: Pengembangan Konsep}

Pada fase pengembangan konsep, kebutuhan pasar target diidentifikasi, alternatif konsep-konsep produk dibangkitkan dan dievaluasi, dan satu atau lebih konsep dipilih untuk pengembangan dan percobaan lebih jauh.

3. Fase 2: Perancangan Tingkat Sistem

Fase perancangan tingkat sistem mencakup definisi arsitektur produk dan uraian produk menjadi subsistem-subsistem serta komponen-komponen

4. Fase 3: Perancangan Detail

Fase perancangan detail mencakup spesifikasi lengkap dari bentuk, material, dan toleransitoleransi dari seluruh komponen unik pada produk dan identifikasi seluruh komponen standar yang dibeli dari pemasok.

\section{Fase 4: Pengujian dan Perbaikan}

Fase pengujian dan perbaikan melibatkan konstruksi dan evaluasi dari bermacammacam versi produksi awal produk.

6. Fase 5: Produksi Awal

Pada fase produksi awal, produk dibuat dengan menggunakan sistem produksi yang sesungguhnya. Tujuan dari produksi awal ini adalah untuk melatih tenaga kerja dalam memecahkan permasalahan yang timbul pada proses produksi sesungguhnya. Peralihan dari produksi awal menjadi produksi sesungguhnya biasanya tahap demi tahap. Pada beberapa titik pada masa peralihan ini, produk diluncurkan dan mulai disediakan untuk didistribusikan

\section{b. Inovasi Produk}

Definisi mengenai pengertian inovasi produk menurut Hurley dan Hult (1998) adalah sebuah mekanisme perusahaan untuk beradaptasi dalam lingkungan yang dinamis. Oleh karena itu, perusahaan dituntut untuk mampu menciptakan pemikiranpemikiran baru, gagasan-gagasan baru, dan menawarkan produk yang lebih inovatif, serta meningkatkan pelayanan yang memuaskan pelanggan. Fontana menyebutkan inovasi produk yang mencakup perubahan-perubahan pada:

1. Bungkus produk, membangun, memperbaiki kemasan suatu produk sehingga lebih inovatif

2. Ukuran produk, adanya keragaman ukuran yang inovatif.

3. Inovasi proses, mengubah maupun membangun proses produksi menjadi lebih efisien. 
4. Inovasi sistem distribusi, membuat saluran distribusi lebih sederhana.

5. Inovasi manajemen, bertujuan membuat manajemen organisasi menjadi lebih fleksibel dan lincah dalam menghadapi perubahan kondisi lingkungan organisasi.

\section{METODE PENELITIAN}

a. Jenis Penelitian

Metode diskriptif dengan pendekatan kualitatif merupakan jenis penelitian yang digunakan dalam penelitian ini. Maksud dari penelitian ini agar peneliti dapat menggambarkan keadaan yang sebenarnya sesuai dengan kenyataan, menggali, dan menganalisis lebih mendalam terkait strategi pengembangan produk dan inovasi produk Teh Hijau Cap Pohon Kurma yang diproduksi oleh PLU. Wawancara, observasi dan dokumentasi adalah pendekatan kualitatif yang diperoleh oleh peneliti.

b. Fokus Penelitian

1. Strategi pengembangan produk Teh Hijau Cap Pohon Kurma produksi PLU

2. Strategi inovasi produk Teh Hijau Cap Pohon Kurma produksi PLU

c. Situs Penelitian

PLU Pekalongan adalah situs penelitian yang digunakan oleh peneliti.

d. Sumber Data

Data primer dan sekunder yang digunakan oleh peneliti. Data primer diperoleh dari wawancara dengan Pejabat Dinas Peridustrian dan Perdagangan, Asosiasi Minuman, agen pemasaran, dan Pejabat PLU.

e. Teknik Pengumpulan Data

Peneliti dalam melakukan penelitian menggunakan observasi, wawancara, dan dokumentasi dalam teknik pengumpulan datanya.

f. Instrumen Penelitian

Recorder, catatan lapangan, pedoman wawancara, dan peneliti sendiri merupakan instrumen yang digunakan oleh peneliti sebagai alat dalam mengumpulkan data.

g. Analisis Data

Model interaktif Miles and Huberman yang digunakan oleh peneliti dalam analisis data. Data collection, data reduction, data display, serta verifying adalah tahapan analisis data yang dipakai peneliti.

h. Keabsahan Data

Peneliti menggunakan teknik keabsahan data berupa triangulasi sumber. Sugiyono (2005) menjelaskan bahwa triangulasi sumber digunakan untuk menguji kredibilitas data yang dilakukan dengan cara mengecek data yang telah diperoleh ke beberapa sumber.

\section{HASIL DAN PEMBAHASAN}

\section{STATEGI PENGEMBANGAN PRODUK}

1. Pemasaran

Produk Teh Hijau Cap Pohon Kurma banyak ditemui pada rak-rak produk berkategori rempah-rempah di supermarket besar maupun kecil. Produk Teh Hijau Cap Pohon Kurma bersaing ketat dalam rak-rak premium pada beberapa supermarket terkenal. Selain itu PLU perlu melakukan modifikasi pasar yaitu pasar yang telah dilayani selama ini dimodifikasi, sehingga para konsumen merasakan keuntungan yang lebih saat mengkonsumsi teh hijau Cap Pohon Kurma dibandingkan saat mengkonsumsi teh hijau lainnya. Ada pun cara modifikasi pasar yang dapat dilakukan antara lain: 
a) Menarik minat bukan pengguna menjadi pengguna produk teh hijau dengan cara meningkatkan iklan dan promosi.

b) Mencari dan memasuki egmen pasar baru. PLU setidaknya mencoba memasuki segmen asar yang belum dimasuki baik pasar domestik maupun pasar luar negeri.

c) Merebut konsumen dari kompetitor. PLU dapat berusaha mempengaruhi konsumen produk teh hijau lainnya agar mau mencoba dan beralih mengkonsumsi Teh Hijau Cap Pohon Kurma. Pada segmen pasar yang sangat peka terhadap mutu maka pengembangan teknologi produk mutlak sangat perlu segera dilakukan.

Dalam analisis pemasaran berdasarkan teori marketing mix ditemukan halhal sebagai berikut:

a) Produk. Produk Teh Hijau Cap Pohon Kurma memang kalah dalam disain dan kemasan. Namun, para konsumen dalam captive marketnya mengakui keunggulan khasiat Teh Hijau Cap Pohon Kurma ini, sehingga konsumen bersedia untuk kembali membeli Teh Hijau Cap Pohon Kurma meskipun kemasannya kurang menarik.

b) Harga. Kemunculan Teh Hijau Cap Pohon Kurma diawali dengan isu khasiat Teh Hijau Cap Pohon Kurma yang mengandung rempah daun benalu teh, sehingga harga premium yang terbentuk benar-benar mengangkat image produk tersebut. Hal ini dapat memperbesar pendapatan dari hasil penjualan khsusunya di tingkat para pengecer, tetapi tidak di tingkat produsen.

c) Tempat. Tempat penjualan Teh Hijau Cap Pohon Kurma adalah di exclusive outlets berupa segmen yang langsung dikenal oleh para retailer karena Teh Hijau Cap Pohon Kurma ini hampir seluruhnya dijual dengan cara direct selling. Sebagian di antara mereka membeli melalui Point of Sales yang bersifat selektif karena mengingat Teh Hijau Cap Pohon Kurma ini sangat terbatas pasokannya.

d) Promosi. Promosi Teh Hijau Cap Pohon Kurma ini dilakukan tanpa menggunakan iklan audio visual. Promosinya hanya dilakukan dengan metode WOM (Words of Mouth).

2. Disain

Produk Teh Hijau Cap Pohon Kurma dikemas dalam alumunium foil dan dibungkus dalam karton tipis berwarna hijau dengan tulisan besar "TEH HIJAU." Pembuatan disain kemasan yang lebih menarik tentu saja didasarkan pada konsep yang pemasaran yang mapan, antara lain:

a) Untuk menarik pelanggan harus memiliki brand yang kuat atau logo yang menarik. Hal ini bisa dilakukan dengan menawarkan produk yang tidak kalah unik dengan pesaing. Di samping itu juga harus bisa mewujudkan produk yang dibutuhkan oleh pelanggan, tetapi ditambahkan dengan nilai plus, sehingga hal tersebut dapat membedakan produk pesaing. Salah satu cara membuat produk yang unik adalah dengan disain kemasan produk yang menarik. Percuma saja jika memiliki brand yang kuat, tetapi tidak memiliki disain kemasan produk yang dapat membuat pelanggan meliriknya. Dengan adanya disain kemasan produk yang unik dan menarik, maka produk akan memasuki tahap untuk diteliti untuk dibeli oleh pelanggan. 
b) Selain faktor pelanggan, disain kemasan produk juga merupakan salah satu aspek yang penting dalam pemasaran. Oleh karena itu, perusahaan harus mendisain kemasan produk sebaik, semenarik, dan seunik mungkin.

c) Mulai mendisain kemasan produk dalam proses pengembangan produk. Membuat sebuah draft beberapa ide untuk mendapatkan visual hasil akhir dari sebuah produk, dalam arti kata harus membayangkan seperti apa produk tersebut jika sudah jadi akan terlihat.

d) Keep It Simple adalah semboyan yang selalu disebutkan oleh para disainer. Dengan menjaga disain kemasan produk agar tetap sederhana, maka akan menguntungkan di kemudian hari. Hal yang perlu diingat adalah bahwa disain kemasan produk harus menyajikan apa yang seharusnya disajikan. Disain kemasan produk harus mengandung detail mengenai produk yang dijual, kemudian untuk memberikan peringatan yang berlaku. Hal ini juga berguna agar mengurangi biaya dalam pembuatan disain kemasan produk.

e) Market Positioning dan Branding merupakan dua hal yang sangat penting dalam pembuatan disain kemasan produk. Dengan mengetahui pasar sasaran yang dituju termasuk ke dalam pengidentifikasian harapan pelanggan terhadap suatu produk akan mendukung efektifitas pemasaran pelanggan. Di samping itu perlu juga dilakukan dengan mengamati kompetitor, karena produk akan menjadi lebih besar hanya dengan mempelajari lawan kompetitor.

f) Produk ini dijual juga secara online, sehingga sedikit berbeda dengan menjualnya secara fisik atau toko brick and mortar. Pelanggan tidak bisa menyentuh dan merasakan produk sebelum membeli, sehingga disain kemasan produk harus menarik bagi indra lainnya, sedangkan jika produk dijual dalam toko fisik, harus dibuat disain kemasan produk jauh lebih menarik, karena produk akan berada dalam rak supermarket yang tentunya berdampingan dengan produk lainnya. Jika disain kemasan produk tidak menarik, maka produk tersebut akan gagal.

3. Manufaktur

Saat ini, konsumen lebih nyaman dengan produk teh yang berbentuk teh celup. PLU segera meluncurkan produk teh hijau dalam kemasan celup, sehingga mampu meningkatkan penjualan produk Teh Hijau Cap Pohon Kurma. Hal lain yang perlu dilakukan PLU adalah melakukan modifikasi produk dengan cara menambah aroma, sehingga konsumen dan pasar termodifikasikan ke arah fase lanjutan dari siklus produk teh hijau tersebut. Dengan cara ini Teh Hijau Cap Pohon Kurma dapat mengubah imagenya dari produk minuman kesehatan menjadi produk minuman segar dan sehat. Ada pun cara untuk modifikasi produk dapat dilakukan dengan cara:

- Peningkatan mutu (Quality Improvement)

- Penambahan features baru (Feature Improvement)

- Peningkatan gaya (Style Improvement).

4. Strategi dan Inovasi Produk

Inovasi sebenarnya mengacu pada suatu barang, jasa, atau pun ide yang dipandang konsumen sebagai sesuatu yang baru. Bisa saja idenya sudah lama, tetapi bagi konsumen, inovasi tersebut dianggap sebagai hal yang baru. Contoh adalah produk 'herbal tea' sebagaimana yang saat ini sedang berkembang di pasar Amerika Serikat. Inovasi biasanya memerlukan waktu yang cukup agar 
dapat tersebar luas ke seluruh segmen pasar dan sistem sosial kemasyarakatan. Hal ini biasa disebut sebagai proses "difusi," oleh Rogers didefinisikan sebagai proses penyebaran ide baru dari pencipta ide baru tersebut hingga sampai kepada para konsumen. Hal tersebut agak berbeda dengan pengertian proses adopsi. Proses adopsi sebenarnya lebih mengarah kepada 'suatu proses mental yang mana seorang konsumen mendengar tentang adanya inovasi tersebut,' sehingga adopsi adalah suatu keputusan dari konsumen untuk menetapkan dirinya sebagai konsumen yang akan secara teratur mengkonsumsi produk yang ditawarkan. Nampaknya, ketiga proses di atas (proses, inovasi, difusi dan adopsi) pada produk teh hijau cukup lancar berjalan, sehingga dalam waktu yang singkat teh hijau mampu dikembangkan dan diterima konsumen. Dalam proses adopsinya, produk Teh Hijau Cap Pohon Kurma dapat digambarkan melalui tahapan sebagai berikut:

a) Pengenalan (Awareness) terhadap produk Teh Hijau Cap Pohon Kurma

Pada fase introduksi ini para konsumen menjadi sadar dan mengenal adanya inovasi produk yang dilakukan, namun masih kekurangan informasi tentang adanya inovasi atau tentang inovasi tersebut. Pada fase ini Teh Hijau Cap Pohon Kurma diperkenalkan oleh para distributor, agen, dan para retailer (salesman) melalui selebaran sederhana.

b) Minat (Interest) terhadap produk Teh Hijau Cap Pohon Kurma

Pada fase ini konsumen sudah terangsang untuk mencari informasi tentang inovasi yang dilakukan oleh perusahaan. Oleh karena itu tindakan perusahaan yang harus segera dilakukan adalah memberikan dan menyediakan informasi mengenai inovasi produk yang telah dia lakukan itu. Pada saat ini PT. PLU menyebarkan informasi melalui brosur yang lebih rinci tentang produk teh hijaunya.

c) Evaluasi (Evaluation) terhadap produk Teh Hijau Cap Pohon Kurma

Pada fase ini, konsumen sudah mulai mempertimbangkan apakah mereka ingin mencoba produk yang telah mengalami inovasi tersebut atau tidak.

d) Coba-coba (Trial) terhadap produk Teh Hijau Cap Pohon Kurma

Pada fase ini konsumen mencoba produk yang telah mengalami inovasi dengan tujuan untuk membandingkan antara estimasi yang dia lakukan dengan nilai dari produk tersebut.

e) Penerimaan (Adoption) terhadap produk Teh Hijau Cap Pohon Kurma

Apabila ternyata konsumen mendapati bahwa inovasi produk yang dilakukan melebihi harapan dia, maka konsumen akan memutuskan untuk menggunakan secara penuh dan secara reguler untuk mengkonsumsi produk tersebut. Hal ini terjadi pada saat tahun ketiga, yaitu ketika produk Teh Hijau Cap Pohon Kurma telah dikemas dalam kemasan aluminium foil.

Kotler (2009) berpendapat bahwa konsumen akan menerima produk yang telah diinovasikan dan akan mau membeli apabila terdapat selisih yang berarti antara total consumer value terhadap total consumer cost. Dengan perkataan lain terdapat suatu nilai positif dari total delivered value (nilai produk total yang diterima konsumen). Di antara usaha PLU agar produk teh hijaunya dapat diterima oleh konsumen baru (new consumers) adalah dengan memposting produk teh hijau 
sebagai teh yang mampu berperan sebagai anti oksidan, sehingga mampu mencegah penyakit kanker sebagaimana yang telah dipromosikan oleh PBB (Perserikatan Bangsa-Bangsa). Pada awalnya, konsumen dapat menerima hal tersebut. Hal ini ditunjukan dari sales (penjualan) yang terus bertambah dari waktu ke waktu. Namun, tampaknya konsumen domestik mulai mengalami kejenuhan akibat rasa dan aroma Teh Hijau Cap Pohon Kurma ini belum dikembangkan lebih lanjut sesuai dengan alur siklus hidupnya. Rasa "bosan" para konsumen ini masih diimbangi oleh potential demand dari para pelanggan yang masih belum sering mengkonsumsi teh hijau akibat pasokan yang terbatas. Para konsumen tipe ini yang menyebabkan penjualan Teh Hijau Cap Pohon Kurma masih tetap terjaga.

\section{KESIMPULAN DAN SARAN}

a. Kesimpulan

Beberapa kesimpulan dapat ditarik dari hasil pembahasan tersebut di atas, di antaranya adalah:

1. Pengembangan produk teh hijau semakin berkembang dengan trend yang bersifat siklikal, sehingga menyebabkan produk teh hijau memiliki pola PLC (Product Life Cycle) berbentuk sinusoidal pendek, dengan perkiraan waktu sekitar 1-10 tahun tergantung kepada tingkat preferensi masyarakat konsumen. Namun, apabila proses pengembangan produk dan inovasi produk dapat dilaksanakan secara "proaktif" (mendahului para pesaingnya), bukan tidak mungkin PLC (Product Life Cycle) dari produk Teh Hijau Cap Pohon Kurma akan berbentuk "scallopped" (meningkat secara periodikal).

2. Teh Hijau Cap Pohon Kurma telah melihat peluang pasar lain selain pasar domestik, yaitu pasar internasional di Amerika Serikat karena trend dari gaya hidup (lifestyle) kebanyakan masyarakat Amerika Serikat menghendaki mereka untuk mengkonsumsi bahan-bahan alami yang menyehatkan. Untuk itu, PLU disarankan mulai melakukan pengembangan dan inovasi produk secara serius apabila ingin melayani pasar global di mana para konsumennya bersikap sangat "demanding" (menuntut).

b. Saran

Untuk itu, penulis merasa perlu pula untuk memberikan masukan (saran) kepada pihak manajemen PLU untuk melakukan hal-hal di bawah ini:

1. Proses pengembangan produk sebaiknya dilakukan secara proaktif dengan tetap memperhatikan kinerja keuangan perusahaan (financial performance) sehingga apa yang diharapkan oleh konsumen di pasar dapat pula memenuhi harapan dari para pemegang saham (stockholders).

2. Pihak manajemen PLU perlu melakukan pengembangan produk dan inovasi produk secara serius dengan melibatkan para praktisi dan akademisi di bidang teh hijau (khususnya) dan dunia bisnis, sehingga dapat masuk dan melayani pasar global di mana para konsumennya bersikap sangat demanding (menuntut).

\section{DAFTAR REFERENSI}

Dharmmesta, B.S. (2007). Azas-azas Marketing. Cetakan Keenam. Edisi Ketiga. Yogyakarta: Liberty Offset. 
Hurley, R.F., Hult, G., \& Tomas, M. (1998). Inovation, Market Orientation, and Organizational Learning: An Intergration and Empirical Examination. Journal of Marketing, July.

Kotler, P. \& Keller, K.L. (2009). Manajemen Pemasaran. Edisi Ke-13. Jilid 1. Jakarta: Penerbit Erlangga.

Parwanto, A. (2011). Pengembangan Produk Baru dan Strategi Siklus Hidup Produk. (http://arwaparwanto.blogspot.com).

Stamm, B.V. (2003). Managing Innovation Design and Creativity. Chichester: John Wiley \& Sons, Ltd.

Sugiyono. (2010). Metode Penelitian Kuantitatif Kualitatif dan R\&D. Bandung: Alfabeta.

Tjiptono, F. (1997). Strategi Pemasaran. Yogyakarta: Andi Offset.

Trott, P. (2008). Innovation Management and New Product Development. Fourth Edition. England: Pearson Education.

Umar, H. (2001). Strategic Management in Action. Jakarta: Gramedia.

White, M.A. \& Bruton, G.D. (2007). The Management of Technology and Innovation: A Strategic Approach. Oklahoma: Thomson South-Western.

Zimmerer, T.W. (1996). Entrepreneurship and New Venture Formation. New Jersey: Prentice-Hall, Inc. 